\title{
The effect of ochratoxin A on egg quality, development of embryos and the level of toxin in eggs and tissues of hens and chicks
}

\section{J. Niemiec ${ }^{1}$, Wanda Borzemska², P. Goliński ${ }^{3}$, Ewa Karpińska ${ }^{2}$, P. Szeleszczuk ${ }^{2}$ and T. Celeda ${ }^{1}$}

\author{
'Department of Poultry Breeding, Warsaw: Agricultural University, \\ Przejazd 4, 05-840 Brwinów, Poland \\ 2 Deparment of Poultry Diseases, Warsan: Agricultural University, \\ Grochowska 272, 03-849 Warsau, Poland \\ ${ }^{3}$ Department of Chemistry, Poznai Agricultural Academy, \\ Wojska Polskiego 75, 60-627 Poznań, Poland
}

(Received 21 November 1994; accepted 19 December 1994)

\begin{abstract}
Six floks, each numbering 11 hens and 1 rooster, of Rhode Island Red strain, at the age of 54 weeks were divided into three groups, and fed on diets containing different amounts of ochratoxin $A$. The control group (1) was fed a standard mixture without ochratoxin A, groups II and III were given the same dict, with 2.1 and $4.1 \mathrm{ppm}$ of ochratoxin A, respectively, introduced with moulded wheat.

The daily feed intake decreased as the ochratoxin A content increased and was 156, 135 and $105 \mathrm{~g} /$ day, respectively. The toxin negatively affected the quality of the eggs, especially thick ness and crushing strength of the shell. Deterioration of egg-shell quality led to greater loss of egg weight during incubation and lower hatchability. As the ochratoxin A content in the feed increased, the percentage of hatched eggs decreased and survival time of embryos dying during incubation declined. The mass of embryos weighted on 6 and 8 day of incubation and the hatched chicks were lower in experimental than in control group. Ochratoxin A was found in the eggs and also in the blood scrum, liver and kidncys of hens, roosters and one-day-old chicks.
\end{abstract}

KEY WORDS: ochratoxin A, laying productivity, egg quality, reproduction, laying hens

\section{INTRODUCTION}

Feeds contaminated with mycotoxins adversely affect health and productivity of hens, egg and meat quality and hatchability indices. It is now considered that 
aflatoxins and ochratoxin $\mathrm{A}$ are the mycotoxins the most harmful to human health and may cause the greatest losses in animal production. According to some authors (Huff and Hamilton, 1974; Huff et al., 1974) ochratoxin A may be more toxic to poultry than aflatoxins. Many reports have been published on the acute and subacute toxicity of ochratoxin A, obtained from cultures of the toxin-producing strain of Aspergillus ochraceus. There is an evidence that after ochratoxin A poisoning laying productivity decline or was completely stopped (Scholtyssek et al., 1987; Niemiec and Scholtyssek, 1987; Choudhury et al., 1971; Prior and Sisodia, 1978; Page et al., 1980), egg-shell damage increased, hatchability deteriorated (Page et al., 1980, Niemiec et al., 1993a,b) and sexual maturation of hens was delayed (Choudhury et al., 1971). These findings motivated us to carry out our previous studies on the effect of this toxin on laying performance and reproduction indices in hens (Bauer et al., 1988; Niemiec and Świerczewska, 1988; Niemiec et al., 1988; Niemiec et al., 1990). The present study is a continuation of earlier experiments.

\section{MATERIAL AND METHODS}

The experiment was carried out on 72 Rhode Island Red hens at the age of 54 weeks. Six flocks ( 11 hens and 1 rooster) having similar laying productivity and percentage of fertilized eggs were selected for the experiment. Three groups of two flocks each were fed for 5 weeks with feed differing in ochratoxin A content. The control group (I) was given a standard diet with no ochratoxin A, groups II and III received the same diet to which 2.1 or $4.1 \mathrm{ppm}$ of the toxin was introduced.

Ochratoxin A was obtained by incubation of wheat with the fungus Aspergillus ochraceus KA 10 (Schindler and Nesheim, 1970). Fermentation was carried out in sterilized Erlenmeyer flasks, each containing $100 \mathrm{~g}$ of moist wheat $(70 \% \mathrm{DM})$. Wheat was incubated for 21 days at $25^{\circ} \mathrm{C}$. After incubation the grains with the mould were dried at room temperature, autoclaved for $1 \mathrm{~min}$ in order to destroy the fungus spores and finely ground. Ochratoxin A content in fermented grain was determined by thin-layer chromatography by the method of Nesheim (1971) modified by Goliński and Szczęsna (1984) and was about 195 ppm per kg.

An appropriate amount of wheat flour containing ochratoxin A was added to the standard mixture to obtain the required concentration of mycotoxin in the experimental diets, while an equal amount of uncontaminated wheat flour was added to the control diet. After 14 days of feeding with the respective diets collection of eggs for hatching and quality assessment began. The quality of the egg-shell was determined by scanning electron microscopy. Three sets of eggs were hatched and the biological quality of each hatched brood was determined. 
After 4 weeks of feeding with the experimental diets, blood was sampled from the wing vein of 4 hens and 2 roosters from each group and pooled. After completion of the experiment the birds were killed and their liver, kidneys and heart were sampled and pooled. Three newly hatched chicks were killed from each of the hatching sets and pooled samples of their blood plasma, kidneys and liver were prepared.

Ochratoxin A was extracted from tissues and determined according to Nesheim (1973). The ochratoxin A content in the eggs was determined by the method described by Piskorska-Pliszczyńska (1984); in blood plasma, according to Mortensen et al. (1983).

\section{RESULTS}

Daily feed intake decreased as the ochratoxin A content increased from 0 to 2.1 and $4.1 \mathrm{ppm}$ and averaged 156, 135 and $105 \mathrm{~g}$ per hen, respectively. The laying performance dropped dramatically, to as low as $16.8 \%$ in group III given the feed containing $4.1 \mathrm{ppm}$ ochratoxin A. After 5 weeks of the experiment the weight of the hens in control group, increased by $33 \mathrm{~g}$, in group II and III decreased by 243 and $340 \mathrm{~g}$, respectively. As the ochratoxin A content in the feed increased, the weight of the eggs and the percentage of egg-shell in the egg decreased (Table 1).

The quality of the eggs deteriorated as the concentration of ochratoxin $\mathrm{A}$ in the feed increased. The largest differences were found in egg-shell quality (Table 1). The shells were thinner, so the eggs showed significantly greater elastic

TABLE 1

Influence of ochratoxin A on egg quality

\begin{tabular}{lccc}
\hline Indices & \multicolumn{3}{c}{ Ochratoxin A content in diet, ppm } \\
& $\mathrm{I}(0)$ & II $(2.1)$ & III $(4.1)$ \\
\hline Number of eggs & 40 & 40 & 40 \\
Average egg weight, g & $62.4^{\mathrm{A}} \pm 0.56$ & $60.3^{\mathrm{A}} \pm 1.32$ & $58.6^{\mathrm{B}} \pm 1.06$ \\
Share in egg, \% & & & \\
- yolk & $29.6^{\mathrm{a}} \pm 0.58$ & $28.7^{\mathrm{b}} \pm 0.91$ & $28.5^{\mathrm{b}} \pm 0.82$ \\
- albumen & $62.3^{\mathrm{B}} \pm 0.85$ & $64.0^{\mathrm{A}} \pm 0.96$ & $64.3^{\mathrm{A}} \pm 1.12$ \\
- shell & $8.1^{\mathrm{A}} \pm 0.31$ & $77^{\mathrm{B}} \pm 0.59$ & $7.2^{\mathrm{B}} \pm 1.05$ \\
Egg-shell & & & \\
- thickness, mm & $0.34^{\mathrm{A}} \pm 0.03$ & $0.3^{\mathrm{B}} \pm 0.07$ & $0.28^{\mathrm{B}} \pm 0.05$ \\
- flexible distortion, $\mu \mathrm{m}$ & $22.0^{\mathrm{C}} \pm 0.05$ & $46.0^{\mathrm{B}} \pm 0.07$ & $81.0^{\mathrm{A}} \pm 0.03$ \\
- crushing strength, $\mathrm{kg} / \mathrm{cm}^{2}$ & $3.16^{\mathrm{a}} \pm 0.27$ & $3.07^{\mathrm{a}} \pm 0.53$ & $3.01^{\mathrm{b}} \pm 0.42$ \\
\hline
\end{tabular}

Means with different superscripts within a row are significantly different $\mathrm{a}, \mathrm{b}-\mathrm{P} \leqslant 0.05 ; \mathrm{A}, \mathrm{B}-\mathrm{P} \leqslant 0.01$ 
TABLE 2

Results of hatching

\begin{tabular}{|c|c|c|c|c|c|}
\hline \multirow[t]{2}{*}{ Group } & \multirow{2}{*}{$\begin{array}{c}\text { Ochratoxin } \\
\mathrm{A} \text { in diet } \\
\text { pmm }\end{array}$} & \multirow{2}{*}{$\begin{array}{l}\text { Number of } \\
\text { incubated } \\
\text { eggs* }\end{array}$} & \multicolumn{2}{|c|}{ Hatchability as $\%$ of eggs } & \multirow{2}{*}{$\begin{array}{l}\text { Mean survival time of } \\
\text { nouvicl embryos, days }\end{array}$} \\
\hline & & & incubated & ferticile & \\
\hline I & 0 & 313 & $83.6^{\mathrm{A}}$ & $87.5^{\mathrm{A}}$ & $13^{a} \pm 0.64$ \\
\hline II & 2.1 & 270 & $79.7^{\mathrm{A}}$ & $82.1^{\mathrm{A}}$ & $12^{\mathrm{a}} \pm 0.97$ \\
\hline III & 4.1 & 68 & $32.3^{\mathrm{B}}$ & $33.3^{\mathrm{B}}$ & $10^{\mathrm{h}} \pm 1.11$ \\
\hline
\end{tabular}

* number of incubated eggs was not equalized, due to lowered laying rate in groups fed diets containing ochratoxin A

Means within a column with different superscripts are significantly different

$\mathrm{a}, \mathrm{b}-\mathrm{P} \leqslant 0.05 ; \mathrm{A}, \mathrm{B}-\mathrm{P} \leqslant 0.01$

deformations and lowered resistance to crushing. The worsening of egg quality, especially of the egg-shell, had a large effect on hatching. Ochratoxin A lowered the number of eggs suitable for hatching and worsened their hatchability. The hatching percentage of fertilized eggs also declined as the ochratoxin A concentration in the feed increased. The greatest decrease was observed in group III fed with a mixture containing $4.1 \mathrm{ppm}$ ochratoxin A. This decline in hatchability was concomitant with a decline in laying output and a shortening of the survival time of the embryos that later died (Table 2).

Biological analysis of the hatch showed very marked effects of ochratoxin A on some of the studied parameters. The thinner shell led to increased egg weight loss during incubation (Table 3). The loss of weight by day 6 in eggs from group III fed $4.1 \mathrm{ppm}$ ochratoxin A in their feed was almost threefold that in the control group. On days 18 and 20 of incubation, the loss of egg weight from hens given the toxin continued to be greater than that in the control eggs.

Feed contaminated with ochratoxin $A$ inhibited the development of embryos (Table 4). The weight of the embryos on 6 and 8 day of incubation, as well as the weight of newly hatched chicks decreased, as the toxin concentration increased.

TABLE 3

Effect of ochratoxin A content in diet on the loss of cgg weight during incubation

\begin{tabular}{|c|c|c|c|c|c|c|}
\hline \multirow[t]{2}{*}{ Group } & \multirow{2}{*}{$\begin{array}{c}\text { Ochratoxin } \\
\mathrm{A} \text { in diet } \\
\text { ppm }\end{array}$} & \multirow{2}{*}{$\begin{array}{c}\text { Number of } \\
\text { incubated } \\
\text { eggs* }\end{array}$} & \multirow{2}{*}{$\begin{array}{c}\text { Initial } \\
\text { egg weight, } \\
\mathrm{g}\end{array}$} & \multicolumn{3}{|c|}{$\begin{array}{c}\text { Loss of egg weight as } \% \text { of initial } \\
\text { egg weight at day }\end{array}$} \\
\hline & & & & 6 & 18 & 20 \\
\hline I & 0 & 313 & $59.3^{n} \pm 0.25$ & $2.2^{A} \pm 0.01$ & $8.8^{A} \pm 0.03$ & $21.1^{\mathrm{A}} \pm 0.18$ \\
\hline II & 2.1 & 270 & $57.3^{8} \pm 0.35$ & $3.8^{\mathrm{B}} \pm 0.03$ & $11.5^{\mathrm{B}} \pm 0.16$ & $25.5^{\mathrm{B}} \pm 0.21$ \\
\hline III & 4.1 & 68 & $54.7^{\mathrm{C}} \pm 0.39$ & $5 . \mathrm{I}^{\mathrm{C}} \pm 0.07$ & $13.7^{\mathrm{C}} \pm 0.18$ & $29.6^{\mathrm{C}} \pm 0.22$ \\
\hline
\end{tabular}

*, a, b; A, B - as in Table 2 
TABLE 4

Effect of ochratoxin A content in diet of hens on the weight of embryos and newly hatched chicks

\begin{tabular}{lcccccc}
\hline $\begin{array}{c}\text { Group } \\
\text { Ochratoxin } \\
\text { A in diet, } \\
\text { ppm }\end{array}$ & $\begin{array}{c}\text { Number of } \\
\text { examined } \\
\text { eggs }\end{array}$ & $\begin{array}{c}\text { Initial } \\
\text { cgg weight. }\end{array}$ & g & \multicolumn{2}{c}{$\begin{array}{c}\text { Weight of cmbryos, } \\
\text { g at day }\end{array}$} & $\begin{array}{c}\text { Weight of newly } \\
\text { hatched chicks, }\end{array}$ \\
\cline { 5 - 6 } & & & & 6 & 18 & $\mathrm{~g}$ \\
I & 0 & 20 & $58.9^{\mathrm{aA}} \pm 1.59$ & $1.15^{\mathrm{A}} \pm 0.38$ & $32.86^{\mathrm{A}} \pm 0.17$ & $45.2^{\mathrm{A}} \pm 0.37$ \\
II & 2.1 & 20 & $57.3^{\mathrm{BA}} \pm 0.64$ & $0.89^{\mathrm{aB}} \pm 0.51$ & $30.22^{\mathrm{aB}} \pm 0.46$ & $41.4^{\mathrm{B}} \pm 0.65$ \\
III & 4.1 & 20 & $54.6^{\mathrm{B}} \pm 0.97$ & $0.77^{\mathrm{bH}} \pm 0.53$ & $28.95^{\mathrm{bB}} \pm 0.26$ & $38.6^{\mathrm{C}} \pm 0.27$ \\
\hline
\end{tabular}

a, b; A, B - as in Table 2

TABLE 5

Content of ochratoxin $A$ in blood plasma, kidneys, livers and hearts of cockerels, hens, newly hatched chicks and in eggs (ppb), detcrmined in pooled samples

\begin{tabular}{|c|c|c|c|c|c|c|c|c|c|}
\hline \multirow[t]{3}{*}{ Item } & \multicolumn{9}{|c|}{ Group } \\
\hline & \multicolumn{3}{|c|}{1} & \multicolumn{3}{|c|}{ II } & \multicolumn{3}{|c|}{ III } \\
\hline & $\overline{3}$ & 0 & $\mathrm{CH}$ & 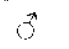 & 9 & $\mathrm{CH}$ & o & 7 & $\mathrm{CH}$ \\
\hline Blood plasma & $\mathrm{ND}^{\mathrm{b}\}}$ & ND & ND & 5.7 & 13.3 & 2.7 & 16.0 & 37.0 & 5.5 \\
\hline Kidneys & ND & ND & ND & 2.9 & 8.1 & 60.6 & 5.9 & 9.0 & 189.0 \\
\hline Liver & ND & ND & ND & 1.3 & 3.3 & 26.0 & 1.7 & 11.9 & 83.0 \\
\hline Heart & ND & ND & - cl $^{c k}$ & 0.07 & 2.1 & - & $\mathrm{ND}$ & 18.6 & - \\
\hline Eggs & - & - & - & - & 4.1 & - & - & 7.9 & - \\
\hline
\end{tabular}

ND - non-detected

- not determined

$\vec{c}$ - cockerels, $q-$ hens, $\mathrm{CH}$ - newly hatched chicks of both sexes

Ochratoxin A was found in the blood plasma, kidneys, livers, hearts and eggs of birds fed mixtures contaminated with this toxin, as well as in the chicks hatched from these eggs (Table 5).

The ochratoxin A concentration was the highest in the kidneys and livers of hens and in the plasma of newly hatched chickens. This confirms earlier information that ochratoxin A permeates into the egg.

\section{DISCUSSION}

Feeding hens diets containing ochratoxin A caused decrease in feed consumption and resulted in a decline or complete stoppage of laying and degradation of egg quality. 
The presented findings are in agreement with the results of Niemiec and Scholtyssek (1987) and Scholtyssek et al. (1987). Also Choudhury et al. (1981) demonstrated the harmful effect of this toxin on productivity, feed consumption and body weight of laying hens. A concentration even as low as $0.5 \mathrm{ppm}$ ochratoxin $\mathrm{A}$ in the diet was shown to be toxic.

Ochratoxin A was found to affect negatively egg quality, mainly the egg shell. A thin shell, less resistant to crushing, had a negative effect on hatching. In an earlier study changes in the ultrastructure of the shell were found, as well as changes in the external and internal shell membranes (Niemiec et al., 1993). This suggests that ochratoxin A caused disturbances in mineral metabolism, which are manifested as a thinner egg-shell. The effect of ochratoxin A on mineral metabolism was demonstrated by Huff et al. (1980) in broiler chicks. In their experiments, the tibia bones of broilers fed a mixture containing $2 \mathrm{ppm}$ ochratoxin A were more prone to breakage, while when $4 \mathrm{ppm}$ of this toxin was fed, also bone diameter decreased.

The harmful effect of ochratoxin $\mathrm{A}$ on hatching indices and mean time of survival of nonviable embryos is in agreement with the results of our earlier experiments (Niemiec et al., 1990) and generally accepted views (Choudhury et al., 1971; Prior and Sisodia, 1978; Page et al., 1980). We could nowhere find a detailed description of the extent of embryos damage. However, in the previous study by Niemiec et al. (1990) attention was focused on morphological deformities, improper positioning and damage to soft tissues and organs of embryos. These results indicate, that the opinion that such disorders may be of genetic origin only, should be revised.

The inhibition of embryo development by the increasing dietary concentrations of ochratoxin A confirms the results of Vesely et al. (1982) and Vesela et al. (1983) who introduced ochratoxin A into developing embryos.

It can be concluded from the few studies on ochratoxin A presence in the tissues of birds that, similarly as in large farm animals, this toxin is quickly absorbed from the digestive tract of the hens and distributed via the blood throughout their entire body. The presence of ochratoxin A in the blood plasma, tissues and eggs of hens fed a contaminated feed agree well with the results of Bauer et al. (1988) and Niemiec et al. (1988). Plant and animal products contaminated with ochratoxin A can therefore be dangerous to humans consuming such food.

\section{CONCLUSIONS}

Feeding hens a diet contaminated with ochratoxin A reduces their laying and breeding performance, as well as exerts a negative effect on the quality of eggs. 
A very strong negative effect of this toxin on the quality of the egg shell was found. The fact that ochratoxin A is transferred to the body of the bird and to the eggs indicates that systematic tests for the presence of mycotoxins in feeds are necessary. Due to the very strong negative effects of ochratoxin A on reproduction and hatching indices, eggs obtained from flocks fed mixtures contaminated with mycotoxins should not be taken for hatching.

\section{REFERENCES}

Bauer J., Niemiec J., Scholtyssek S., 1988. Ochratoxin im Legehennenfutter 2. Mitteilung: Rückstände in Serum, Leber und Ei. Arch. Geflügelk. 52, 71-75

Choudhury H., Carlson C.W., Semeniuk G., 1971. A study of ochratoxin toxicity in hens. Poultry Sci. 50, 1855-1959

Goliński P., Grabarkiewicz-Szczęsna J., 1984. Chemical confirmatory tests for ochratoxin A, citrinin, penicillic acid, sterigmatocistin and zearalenone, performed directly on thin layer chromatographic plates. J. Assoc. Off. Anal. Chem. 67, 1108-1110

Huff W.E., Hamilton P.B., 1974. Nephrotoxicity of ochratoxin A in broiler chicks. Poultry Sci. 53, 1937-1938

Huff W.E., Wyatt R.D., Tucker T.L., Hamilton P.B., 1974. Ochratoxicosis in the broiler chicken. Poultry Sci. 53, 1585-1591

Huff W.E., Doerr J.A., Hamilton P.B, Hamann D.D., Peterson R.E., Ceigler A., 1980. Evaluation of bone strength during aflatoxicosis and ochratoxicosis. Appl. Environ. Microbiol. 40, 102-107

Mortensen H.P., Hald B., Madsen A., 1983. Feeding experiment with ochratoxin A contamined barley for bacon pigs. 5. Ochratoxin A in pig blood. Acta Agric. Scand. 33, 238-239

Nesheim S., 1971. Ochratoxins: occurrence, production, analysis and toxicity. 85th Annual Meeting of the Association of Official Analytical Chemists, Washington, Abstr. 23

Nesheim S., 1973. Analysis of ochratoxin A and B in barley using partition and thin layer chromatography. I. Development of the method. J. Assoc. Off. Anal. Chem. 56, 817-821

Niemiec J., Cywa-Benko K., Stępińska M., Wężyk S., Świerczewska E., 1993a. Effect of ochratoxin A on ultrastucture of egg-shell in Rhode Island Red hens. Proceedings of 5th European Symposium on the Quality of Eggs and Egg Products, Tours, 163-173

Niemiec J., Goliński P., Borzemska W., Świerczewska E., Stępińska M., 1993b. The effect of ochratoxin A contained in the mixture for layers on the results of hatch. Zesz. Nauk. PTZ, 8, Chów i hodowla drobiu, 252-257

Niemiec J., Roszkowski J., Borzemska W., Karpińska E., 1990. Influence of ochratoxin A contaminated feed on chick embryogenesis. Arch. Geflügelk. 54, 70-73

Niemiec J., Scholtyssek S., 1987. Influence of ochratoxin A on egg production in Leghorn-type hens. Presented at the XV Polish Congres Poultry Sci., Bydgoszcz, September

Niemiec J., Scholtyssek S., Bauer J., 1988. Ochratoxin A im Broilerfutter: Einfluss auf die Gewichtsentwicklung und Rücstande im Gewebe. Arch. Geflügelk. 52, 163-168

Niemiec J., Świerczewska E., 1988. The effect of ochratoxin A on health and productivity of broiler chickens. VI Sympozjum Produkcji Drobiu, Aspekty zootechniczno-weterynaryjne chowu kur mięsnych, Polanica-Zdrój, September

Page R.K., Stewart G., Wyatt R., Buch P., Fletcher O.J., Brown J., 1980. Influence of low levels of ochratoxin A on egg production, egg-shell strains and serum uric acid levels in Leghorn-type hens. Avian Dis. 24, 777-780 
Piskorska-Pliszczyńska J., 1984. Determination of ochratoxin A in feeds, tissues and eggs (in Polish). Bromatol. Chem. Toksykol. 17, 327-330

Prior M.G., Sisodia S.C., 1978. Ochratoxicosis in White Leghorn hens. Poultry Sci. 57, 619-623

Prior M.G., Sisodia S.C., O'Neil J.B., 1981. Effect of ochratoxin A on egg production, body wcight and feed intake in White Leghorn hens. Poultry Sci. 60, 1145-1148

Schindler A.F., Nesheim S., 1970. Effect of moisture and incubation time on ochratoxin A production by isolate of Aspergillus ochraceus. J. Assoc. Off. Anal. Chem. 53, 89-91

Scholtyssek S., Niemiec J., Bauer I., 1987. Ochratoxin A im Legehennenfutter. 1. Mitteilung: Einfluss auf Legeleistung und Eiqualität. Arch. Geflügelk. 51, 234-240

Vesely D., Vesela D.. Jelinek R., 1982. Nineteen mycotoxins tested on embryos. Toxic. Letters. 13, 239-243

Vesela D., Vesely D., Jelinek R., 1983. Toxic effects of ochratoxin A and citrinin, alone and in combination, on chicken embryos. Appl. Environ. Microbiol. 45, 91-93

\section{STRESZCZENIE}

\section{Wpływ ochratoksyny A w mieszance kur niosek na jakość jaj i wyniki wylęgu}

Sześć stadek liczących każde po 11 kur i 1 koguta rasy Rhode Island Red w wieku 54 tygodni podzielono na 3 grupy, które żywiono mieszanką o różnej zawartości ochratoksyny A. Grupa kontrolna (I) żywiona byla standardową mieszanką nie zawierającą ochratoksyny A, a grupy II i III mieszankami, które zawierały odpowiednio 2,1 i 4,1 ppm tej toksyny.

Dzicnne spożycic micszanki zmnicjszało się wraz ze wzrostem zawartości ochratoksyny A w paszy $(0 ; 2,1 ; 4,1 \mathrm{ppm})$ i wynosilo odpowiednio 156,135 i $105 \mathrm{~g} /$ dzień. Toksyna ta pogarszala jakość jaj, przy crym największe różnice dotycryły jakości skorupy. Wsk utek cienszej skorupy jaja te charakteryzowały się większym odkształceniem elastycznym oraz zmniejszoną wytrzymalością na zgniatanie.

Pogorszenie jakości skorupy miało wpływ na straty masy jaj podczas inkubacji oraz zdolność wylęgową piskląt. Wraz ze wzrostem skażenia mieszanki ochratoksyną A obniżał się procent wylęgu z jaj zapłodnionych oraz skracal się czas przeżycia zarodków. Kontrolne ważenic zarodków w 6 i 18 dobic inkubacji a także wyklutych piskląt wykazało zahamowanie rozwoju zarodków pod wpływem tej toksyny. Stwierdzono obecność ochratoksyny A w jajach. a także w osoczu krwi oraz w wątrobie i nerkach kur, kogutów i jednodniowych piskląt. 